\title{
POST-FIRE RESPROUTING AND MORTALITY IN CERRADO WOODY PLANT SPECIES OVER A THREE-YEAR PERIOD
}

\author{
M. B. MedeIROS ${ }^{1} \&$ H.S. Miranda ${ }^{2}$
}

The objective of this work was to evaluate resprouting features and mortality in Cerrado woody plants after annual controlled fires (in 1998, 1999 and 2000) in a campo sujo area (an open savanna physiognomy) of $2500 \mathrm{~m}^{2}$ at the Reserva Ecológica do IBGE, Brasília$\mathrm{DF}, \mathrm{Brazil}$. The area was protected against fire for 23 years prior to the fires. All plants of the woody layer with diameter larger than $2.0 \mathrm{~cm}$ at $30 \mathrm{~cm}$ from soil level were tagged and identified. At about one year after each controlled fire the damage type and the number of basal and underground sprouts for each individual were recorded. Stem diameter and height were measured for each marked sprout. A total of 1307 sprouts were tagged and measured. The main impact of fire on resprouting was a decrease in the number of new sprouts after each controlled fire: 684 sprouts after the first burning to 248 after the third burning. Mortality of sprouts was $34.8 \%$ and $37.8 \%$ after the 1999 and 2000 fires. A decrease in the number of sprouts with a diameter smaller than $1.0 \mathrm{~cm}$ after the successive fires was also observed, indicating that fires at one-year intervals resulted in alterations in the structure of the woody vegetation in the area. The species mortality rates were higher after the first controlled fire. However, it seems that there is no relation between sprouting capacity and species survival. The species that show mortality rates lower than $10 \%$ also showed a variety of sprouting capacity.

Keywords. Brazil, Cerrado, fire, mortality, sprouts, woody plants.

\section{INTRODUCTION}

After fires, Cerrado woody vegetation will sprout in a short period (Coutinho, 1990). This resprouting capacity is due to various adaptations: the presence of tubers that store water and nutrients (Rizzini \& Heringer, 1962), the high insulation capacity of thick bark (Rocha-Silva \& Miranda, 1996), and protection of apical buds by a sleeve of densely packed persistent leaf bases (Coutinho, 1990). Although sprouting is a common vegetative recovery event after fire (Frost \& Robertson, 1987; Kauffman, 1991; Agee, 1993; Vesk, 2006), frequent fires should favour particularly those species with the most effective resprouting capacity (Bond \& Wilgen, 1996; Hoffmann, 1999; Braz et al., 2000).

\footnotetext{
${ }^{1}$ Embrapa Recursos Genéticos e Biotecnologia, Prédio da Botânica e Ecologia, Av. W 3 Norte s/nº, CP 02372, CEP 70770-900, Brasília-DF, Brazil. E-mail: medeiros@cenargen.embrapa.br

${ }^{2}$ Universidade de Brasília, Campus Universitário Darcy Ribeiro, Instituto de Ciências Biológicas, Departamento de Ecologia, Asa Norte, CEP 70910-900, Brasília-DF, Brazil.
} 
High fire frequency, as observed in the Cerrado region (Coutinho, 1990), results not only in the mortality of a large percentage of individuals but also in a high proportion of plants suffering topkill (Hoffmann \& Solbrig, 2003; Medeiros \& Miranda, 2005; Miranda \& Sato, 2005). The expansion of new leaves of most of the woody Cerrado vegetation occurs during the dry season (Oliveira \& Gibbs, 2000), and the resprouting of individuals suffering topkill is expensive in terms of nutrients to recover the aerial parts of the plants (Hoffmann, 1998). Under high fire frequency the repeated demand for nutrients to recover the vegetative structure would result in a reduction in the number of new sprouts and in the height of the plant community.

The objective of this work was to evaluate resprouting after annual controlled fires (in 1998, 1999 and 2000) in woody plants in a campo sujo area (an open savanna physiognomy) that had previously been protected from fire for 23 years. In this study the effect is reported of three successive annual controlled fires on the production and mortality of basal and/or underground sprouts.

\section{Material and Methods}

\section{Study area}

The study was carried out at the Reserva Ecológica do Instituto Brasileiro de

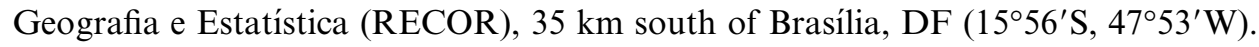
The climate in the region is Cwa in Köppen's classification, with a mean temperature of $21^{\circ} \mathrm{C}$. Most of the total annual precipitation $(1436 \mathrm{~mm})$ occurs from October to May. The altitude varies from 1048 to $1150 \mathrm{~m}$. The RECOR reserve has an area of 1360 ha and most of the characteristic physiognomies of Cerrado are represented. These vary from open forms like campo limpo, grassland with no woody plants, and campo sujo, with a predominance of herbaceous species with some shrubs and subshrub species, to forest physiognomies in which grasses are excluded. (Many works describe the various forms of Cerrado; see for example Eiten, 1972; Ribeiro \& Walter, 1998.)

The study was carried out in a campo sujo area of $2500 \mathrm{~m}^{2}$ that had been protected from fire for 23 years. In spite of the period of time the vegetation was left unburned a closed typical Cerrado had not established. This was probably due to the shallowness of the soils. In 1998, 1999 and 2000, fires were initiated at the beginning of August (middle of the dry season), the time of year when most Cerrado fires are registered in the region (Dias, 1992).

\section{Vegetation inventory}

In 1998, before the first controlled fire, all shrubs and trees in the study area with stem diameter equal to or greater than $2.0 \mathrm{~cm}$ at $30 \mathrm{~cm}$ above soil level were tagged, identified, and their height and diameter recorded. One month before the next fire, 
the height and diameter measurements were repeated for the same individuals. For each individual, the damage that resulted from the previous controlled fire was recorded. We divided the response to fire into four categories: individuals with aerial sprouts; individuals with basal and/or underground sprouts (the latter emerging from the soil up to $30 \mathrm{~cm}$ from the stem); topkill with basal and/or underground sprouts; and total damage (death of the individual).

\section{Sprout inventory}

All stems arising from basal or subterranean sprouts were tagged and their basal diameter and height recorded. The data were collected only one month before the next controlled fire to allow the maximum sprout growth to be achieved.

The plant community-resprouting index $(R I)$ was calculated according to Ramos (1990):

$$
R I=\frac{L}{D+L i}
$$

where $L$ is the number of basal and underground sprouts added to the number of live individuals, $D$ is the number of individuals that died as a consequence of the previous fires and $L i$ is the number of live individuals.

\section{Species mortality}

The mortality by species was measured after each controlled fire, including all individuals that died and did not produce new sprouts.

The software Bioestat 3.0 (Ayres et al., 2003) was used to analyse the data. The $\chi^{2}$ test $(P<0.05)$ was used to compare proportion data and the non-parametric Friedman test $(P<0.05)$ was used to compare the different sprout types in the different burnings.

\section{RESULTS}

\section{Post-fire resprouting}

In 1998, before the first controlled fire, there were a total of 636 live individuals in the area, distributed across 39 species. Mortality as a consequence of the 1998, 1999 and 2000 burnings was $22.5 \%, 7.9 \%$ and $11.5 \%$, respectively, resulting in a reduction of $37 \%$ in the number of live individuals (Medeiros \& Miranda, 2005). Almost 50\% of the live individuals had aerial sprouts or aerial sprouts with basal and/or underground sprouts after the fires (Table 1). The number of individuals with basal and/or underground sprouts suffering topkill increased after the 1999 fire and after the succeeding one. There were no significant differences between the fires for the different sprout types: aerial, basal and underground sprouts (Friedman test $(\mathrm{Fr})=1.0 ; P>$ $0.05)$, basal and underground $(\mathrm{Fr}=5.7 ; P>0.05)$ and aerial $(\mathrm{Fr}=1.4 ; P>0.05)$. 
T A BLE 1. Sprout type, number of individuals $(N)$ and relative frequency (RF) after the 1998, 1999 and 2000 controlled fires, registered in the following years $(1999,2000,2001)$ to allow time for development of sprouts

\begin{tabular}{|c|c|c|c|c|c|c|}
\hline \multirow[b]{2}{*}{ Sprout type } & \multicolumn{2}{|c|}{1998} & \multicolumn{2}{|c|}{1999} & \multicolumn{2}{|c|}{2000} \\
\hline & $N$ & RF (\%) & $N$ & RF $(\%)$ & $N$ & $\mathrm{RF}(\%)$ \\
\hline Aerial & 232 & 47.0 & 182 & 40.0 & 119 & 29.5 \\
\hline Basal & 179 & 36.3 & 206 & 45.2 & 214 & 53.1 \\
\hline Underground & 3 & 0.6 & 19 & 4.2 & 16 & 4.0 \\
\hline Aerial and basal & 58 & 11.8 & 31 & 6.8 & 41 & 10.2 \\
\hline Aerial and underground & 6 & 1.2 & 2 & 0.4 & 6 & 1.5 \\
\hline Aerial, basal and underground & 3 & 0.6 & 3 & 0.7 & 2 & 0.5 \\
\hline Basal and underground & 12 & 2.4 & 12 & 2.7 & 5 & 1.2 \\
\hline Total & 493 & 100.0 & 455 & 100.0 & 403 & 100.0 \\
\hline
\end{tabular}

The species present in the area and the sprout type per species one year after each annual controlled fire are shown in Table 2. Byrsonima crassa, Byrsonima sp., Caryocar brasiliense, Dalbergia miscolobium, Hancornia speciosa, Heteropterys byrsonimifolia, Miconia albicans, Psidium pohlianum, Qualea grandiflora, Symplocos rhamnifolia and Vellozia squamata had only aerial sprouts.

A second group of species included those that showed three forms of resprouting, i.e. aerial, basal, underground and combined forms: Acosmium dasycarpum, Andira vermifuga, Aspidosperma tomentosum, Byrsonima verbascifolia, Connarus suberosus, Davilla elliptica, Dimorphandra mollis, Schefflera macrocarpa, Enterolobium gummiferum, Eremanthus goyazensis, Erythroxylum suberosum, Erythroxylum deciduum, Erythroxylum tortuosum, Kielmeyera coriacea, Ouratea hexasperma, Palicourea rigida, Qualea parviflora, Roupala montana, Rourea induta, Stryphnodendron adstringens and Styrax ferrugineus.

There was a decrease in the number of basal and/or underground sprouts after each annual burning. After the first burning (1998) 684 such sprouts were tagged. Only 375 new sprouts were tagged after the second burning and 248 after the 2000 prescribed fire (Table 3). Among the species with more than 10 individuals, only Acosmium dasycarpum and Vellozia squamata (which produces only aerial sprouts) did not show an initial increase and a subsequent decrease in the number of individuals with basal and underground sprouts after the burnings.

Some of the species with more than 10 individuals showed a relatively high number of basal and underground sprouts (Table 3). Byrsonima coccolobifolia, Connarus suberosus, Eremanthus goyazensis, Kielmeyera coriacea, Neea theifera, Ouratea hexasperma and Styrax ferrugineus had, on average, 1.4 sprouts/individual. For these species there was a significant reduction $(\mathrm{Fr}=17.2 ; P<0.05)$ in the number of sprouts after the second burning, suggesting that annual fires will affect the structure of the different species populations. 
T A B LE 2. Sprout types per species after the annual controlled fires of 1998, 1999 and 2000, registered in the following years (1999, 2000, 2001) to allow time for development of sprouts

\begin{tabular}{|c|c|c|c|c|c|c|c|c|c|c|}
\hline \multirow[b]{2}{*}{ Species } & \multirow{2}{*}{$\begin{array}{l}\text { No. of } \\
\text { individuals }\end{array}$} & \multicolumn{3}{|c|}{$\begin{array}{l}\text { Individuals with } \\
\text { AUB sprouts }\end{array}$} & \multicolumn{3}{|c|}{$\begin{array}{l}\text { Individuals with } \\
\text { UB sprouts }\end{array}$} & \multicolumn{3}{|c|}{$\begin{array}{l}\text { Individuals with } \\
\text { A sprouts }\end{array}$} \\
\hline & & 1998 & 1999 & 2000 & 1998 & 1999 & 2000 & 1998 & 1999 & 2000 \\
\hline Acosmium dasycarpum (Vogel) Yakovlev & 54 & 1 & 0 & 0 & 22 & 23 & 21 & 9 & 3 & 5 \\
\hline Andira vermifuga Mart. & 4 & 0 & 0 & 0 & 3 & 3 & 3 & 1 & 1 & 1 \\
\hline Annona crassiflora Mart. & 1 & 0 & 0 & 0 & 0 & 0 & 0 & 0 & 0 & 0 \\
\hline Aspidosperma tomentosum Mart. & 2 & 0 & 0 & 0 & 1 & 1 & 1 & 1 & 1 & 1 \\
\hline Byrsonima coccolobifolia Kunth & 7 & 0 & 0 & 0 & 1 & 3 & 3 & 6 & 4 & 4 \\
\hline Byrsonima crassa Ndz. & 5 & 0 & 0 & 0 & 0 & 0 & 0 & 5 & 5 & 5 \\
\hline Byrsonima sp. & 1 & 0 & 0 & 0 & 0 & 0 & 0 & 1 & 1 & 1 \\
\hline Byrsonima verbascifolia (L.) DC. & 28 & 1 & 2 & 2 & 0 & 1 & 1 & 24 & 24 & 23 \\
\hline Caryocar brasiliense Cambess. & 2 & 0 & 0 & 0 & 0 & 0 & 0 & 2 & 1 & 1 \\
\hline Casearia sylvestris $\mathrm{Sw}$. & 1 & 0 & 0 & 0 & 1 & 1 & 1 & 0 & 0 & 0 \\
\hline Connarus suberosus Planch. & 14 & 3 & 1 & 1 & 6 & 9 & 9 & 2 & 2 & 2 \\
\hline Dalbergia miscolobium Benth. & 1 & 0 & 0 & 0 & 0 & 0 & 0 & 1 & 1 & 1 \\
\hline Davilla elliptica A.St.-Hil. & 92 & 17 & 6 & 6 & 16 & 22 & 26 & 52 & 57 & 53 \\
\hline Dimorphandra mollis Benth. & 12 & 1 & 0 & 0 & 3 & 4 & 5 & 8 & 8 & 7 \\
\hline Enterolobium gummiferum (Mart.) J.Macbr. & 5 & 0 & 0 & 0 & 0 & 2 & 2 & 2 & 2 & 2 \\
\hline Eremanthus goyazensis (Gardn.) Sch.Bip. & 37 & 9 & 4 & 4 & 20 & 25 & 25 & 3 & 2 & 1 \\
\hline Erythroxylum daphnites Mart. & 1 & 0 & 0 & 0 & 0 & 0 & 0 & 0 & 0 & 0 \\
\hline Erythroxylum deciduum A.St.-Hil. & 8 & 0 & 1 & 1 & 4 & 5 & 5 & 2 & 2 & 2 \\
\hline Erythroxylum suberosum A.St.-Hil. & 22 & 0 & 2 & 2 & 5 & 5 & 5 & 15 & 12 & 12 \\
\hline Erythroxylum tortuosum Mart. & 2 & 0 & 0 & 0 & 1 & 1 & 1 & 0 & 1 & 2 \\
\hline Hancornia speciosa Gomez & 1 & 0 & 0 & 0 & 0 & 0 & 0 & 1 & 1 & 1 \\
\hline Heteropterys byrsonimifolia A.Juss. & 2 & 0 & 0 & 0 & 0 & 0 & 0 & 1 & 2 & 2 \\
\hline Kielmeyera coriacea (Spreng.) Mart. & 37 & 3 & 2 & 2 & 11 & 17 & 17 & 16 & 11 & 8 \\
\hline Miconia albicans (Sw.) Triana & 1 & 0 & 0 & 0 & 0 & 0 & 0 & 1 & 1 & 1 \\
\hline Neea theifera Oerst. & 6 & 0 & 0 & 0 & 6 & 5 & 5 & 0 & 0 & 0 \\
\hline Ouratea hexasperma (A.St.-Hil.) Baill. & 38 & 20 & 12 & 7 & 7 & 12 & 12 & 8 & 12 & 16 \\
\hline
\end{tabular}


TABLe 2. (Cont'd $)$

\begin{tabular}{|c|c|c|c|c|c|c|c|c|c|c|}
\hline \multirow[b]{2}{*}{ Species } & \multirow{2}{*}{$\begin{array}{l}\text { No. of } \\
\text { individuals }\end{array}$} & \multicolumn{3}{|c|}{$\begin{array}{l}\text { Individuals with } \\
\text { AUB sprouts }\end{array}$} & \multicolumn{3}{|c|}{$\begin{array}{l}\text { Individuals with } \\
\text { UB sprouts }\end{array}$} & \multicolumn{3}{|c|}{$\begin{array}{l}\text { Individuals with } \\
\text { A sprouts }\end{array}$} \\
\hline & & 1998 & 1999 & 2000 & 1998 & 1999 & 2000 & 1998 & 1999 & 2000 \\
\hline Palicourea rigida Kunth & 7 & 0 & 0 & 0 & 3 & 3 & 3 & 4 & 3 & 3 \\
\hline Piptadenia sp. & 1 & 0 & 0 & 0 & 1 & 1 & 1 & 0 & 0 & 0 \\
\hline Psidium pohlianum O.Berg & 1 & 0 & 0 & 0 & 0 & 0 & 0 & 1 & 1 & 1 \\
\hline Qualea grandiflora Mart. & 9 & 0 & 0 & 0 & 0 & 0 & 0 & 9 & 9 & 9 \\
\hline Qualea parviflora Mart. & 3 & 0 & 0 & 0 & 1 & 1 & 1 & 2 & 2 & 2 \\
\hline Roupala montana Aubl. & 123 & 6 & 7 & 7 & 38 & 46 & 45 & 26 & 12 & 8 \\
\hline Rourea induta Planch. & 20 & 2 & 1 & 1 & 11 & 14 & 13 & 0 & 1 & 2 \\
\hline Schefflera macrocarpa (Seem.) D.C.Frodin & 4 & 0 & 0 & 0 & 2 & 2 & 2 & 2 & 2 & 2 \\
\hline Stryphnodendron adstringens (Mart.) Cov. & 4 & 1 & 1 & 1 & 0 & 0 & 0 & 3 & 3 & 3 \\
\hline Styrax ferrugineus Nees \& Mart. & 42 & 2 & 1 & 1 & 22 & 30 & 30 & 8 & 4 & 2 \\
\hline Symplocos rhamnifolia A.DC. & 4 & 0 & 0 & 0 & 0 & 0 & 0 & 4 & 4 & 4 \\
\hline Vellozia squamata Pohl & 34 & 0 & 0 & 0 & 0 & 0 & 0 & 22 & 25 & 21 \\
\hline
\end{tabular}

$\mathrm{AUB}=$ aerial, underground and basal; $\mathrm{UB}=$ underground and basal; $\mathrm{A}=$ aerial. 
TABLE 3. Number of basal and underground (BU) sprouts per species and the mean number of BU sprouts per individual (standard deviation in parentheses) after the annual controlled fires in 1998, 1999 and 2000, registered in the following years $(1999,2000,2001)$ to allow time for development of sprouts

\begin{tabular}{|c|c|c|c|c|c|c|}
\hline \multirow[b]{2}{*}{ Species } & \multicolumn{2}{|l|}{1998} & \multicolumn{2}{|l|}{1999} & \multicolumn{2}{|l|}{2000} \\
\hline & $\begin{array}{l}\text { No. of } \\
\text { sprouts }\end{array}$ & $\begin{array}{l}\text { Sprouts/ } \\
\text { ind. }\end{array}$ & $\begin{array}{l}\text { No. of } \\
\text { sprouts }\end{array}$ & $\begin{array}{l}\text { Sprouts/ } \\
\text { ind. }\end{array}$ & $\begin{array}{l}\text { No. of } \\
\text { sprouts }\end{array}$ & $\begin{array}{l}\text { Sprouts/ } \\
\text { ind. }\end{array}$ \\
\hline $\begin{array}{l}\text { Acosmium dasycarpum (Vogel) } \\
\text { Yakovlev }\end{array}$ & 40 & $0.7(0.6)$ & 18 & $0.3(0.8)$ & 11 & $0.2(0.7)$ \\
\hline Andira vermifuga Mart. & 5 & $1.2(0.7)$ & 4 & $1.0(0.8)$ & 4 & $1.0(0.8)$ \\
\hline Annona crassiflora Mart. & 2 & $2.0(0.0)$ & 0 & $0.0(0.0)$ & 0 & $0.0(0.0)$ \\
\hline Aspidosperma tomentosum Mart. & 3 & $1.5(0.7)$ & 3 & $1.5(0.7)$ & 2 & $1.0(0.0)$ \\
\hline Byrsonima coccolobifolia Kunth & 16 & $2.3(0.7)$ & 12 & $1.7(0.6)$ & 8 & $1.1(0.6)$ \\
\hline Byrsonima crassa $\mathrm{Ndz}$ & 0 & $0.0(0.0)$ & 0 & $0.0(0.0)$ & 0 & $0.0(0.0)$ \\
\hline Byrsonima sp. & 0 & $0.0(0.0)$ & 0 & $0.0(0.0)$ & 0 & $0.0(0.0)$ \\
\hline Byrsonima verbascifolia (L.) DC. & 1 & $0.1(0.2)$ & 1 & $0.1(0.2)$ & 1 & $0.1(0.2)$ \\
\hline Caryocar brasiliense Cambess. & 1 & $0.5(0.7)$ & 1 & $0.5(0.5)$ & 1 & $0.5(0.7)$ \\
\hline Casearia sylvestris $\mathrm{Sw}$. & 3 & $3.0(0.0)$ & 3 & $3.0(0.0)$ & 3 & $3.0(0.0)$ \\
\hline Connarus suberosus Planch. & 23 & $1.6(1.2)$ & 15 & $1.1(0.6)$ & 10 & $0.7(0.7)$ \\
\hline Dalbergia miscolobium Benth. & 0 & $0.0(0.0)$ & 0 & $0.0(0.0)$ & 0 & $0.0(0.0)$ \\
\hline Davilla elliptica A.St.-Hil. & 108 & $1.2(0.9)$ & 75 & $0.8(0.7)$ & 53 & $0.6(0.8)$ \\
\hline Dimorphandra mollis Benth. & 7 & $0.6(1.1)$ & 5 & $0.4(1.0)$ & 5 & $0.4(1.0)$ \\
\hline $\begin{array}{l}\text { Enterolobium gummiferum (Mart.) } \\
\text { J.Macbr. }\end{array}$ & 0 & $0.0(0.0)$ & 5 & $0.0(0.0)$ & 0 & $0.0(0.0)$ \\
\hline $\begin{array}{l}\text { Eremanthus goyazensis (Gardn.) } \\
\text { Sch.Bip. }\end{array}$ & 55 & $1.5(0.6)$ & 35 & $0.9(0.6)$ & 20 & $0.5(0.7)$ \\
\hline Erythroxylum daphnites Mart. & 0 & $0.0(0.0)$ & 0 & $0.0(0.0)$ & 0 & $0.0(0.0)$ \\
\hline Erythroxylum deciduum A.St.-Hil. & 6 & $0.7(0.6)$ & 5 & $0.6(0.4)$ & 5 & $0.6(0.4)$ \\
\hline Erythroxylum suberosum A.St.-Hil. & 9 & $0.4(0.9)$ & 6 & $0.3(0.5)$ & 4 & $0.2(0.5)$ \\
\hline Erythroxylum tortuosum Mart. & 3 & $1.5(0.7)$ & 3 & $1.5(0.7)$ & 3 & $1.5(0.7)$ \\
\hline Hancornia speciosa Gomez & 0 & $0.0(0.0)$ & 0 & $0.0(0.0)$ & 0 & $0.0(0.0)$ \\
\hline Heteropterys byrsonimifolia A.Juss. & 0 & $0.0(0.0)$ & 0 & $0.0(0.0)$ & 0 & $0.0(0.0)$ \\
\hline Kielmeyera coriacea (Spreng.) Mart. & 55 & $1.5(0.6)$ & 24 & $0.6(0.8)$ & 15 & $0.4(0.6)$ \\
\hline Miconia albicans (Sw.) Triana & 0 & $0.0(0.0)$ & 0 & $0.0(0.0)$ & 0 & $0.0(0.0)$ \\
\hline Neea theifera Oerst. & 24 & $4.0(0.8)$ & 14 & $2.3(0.6)$ & 12 & $2.0(0.8)$ \\
\hline $\begin{array}{l}\text { Ouratea hexasperma (A.St.-Hil.) } \\
\text { Baill. }\end{array}$ & 63 & $1.7(0.5)$ & 26 & $0.7(0.5)$ & 14 & $0.4(0.6)$ \\
\hline Palicourea rigida Kunth & 9 & $1.3(0.7)$ & 6 & $0.9(0.7)$ & 5 & $0.7(0.5)$ \\
\hline Piptadenia sp. & 1 & $1.0(0.0)$ & 1 & $1.0(0.0)$ & 1 & $1.0(0.0)$ \\
\hline Psidium pohlianum O.Berg & 0 & $0.0(0.0)$ & 0 & $0.0(0.0)$ & 0 & $0.0(0.0)$ \\
\hline Qualea grandiflora Mart. & 0 & $0.0(0.0)$ & 0 & $0.0(0.0)$ & 0 & $0.0(0.0)$ \\
\hline Qualea parviflora Mart. & 4 & $1.3(1.1)$ & 3 & $1.0(1.0)$ & 3 & $1.0(1.0)$ \\
\hline Roupala montana Aubl. & 114 & $0.9(0.9)$ & 42 & $0.3(0.6)$ & 26 & $0.2(0.6)$ \\
\hline Rourea induta Planch. & 27 & $1.3(0.7)$ & 16 & $0.8(0.6)$ & 16 & $0.8(0.6)$ \\
\hline $\begin{array}{l}\text { Schefflera macrocarpa (Seem.) } \\
\text { D.C.Frodin }\end{array}$ & 3 & $0.7(0.5)$ & 3 & $0.7(0.5)$ & 3 & $0.7(0.5)$ \\
\hline $\begin{array}{l}\text { Stryphnodendron adstringens } \\
\text { (Mart.) Cov. }\end{array}$ & 3 & $0.8(1.0)$ & 2 & $0.5(0.6)$ & 2 & $0.5(0.6)$ \\
\hline
\end{tabular}


TABle 3. (Cont'd)

\begin{tabular}{|c|c|c|c|c|c|c|}
\hline \multirow[b]{2}{*}{ Species } & \multicolumn{2}{|l|}{1998} & \multicolumn{2}{|l|}{1999} & \multicolumn{2}{|l|}{2000} \\
\hline & $\begin{array}{l}\text { No. of } \\
\text { sprouts }\end{array}$ & $\begin{array}{l}\text { Sprouts/ } \\
\text { ind. }\end{array}$ & $\begin{array}{l}\text { No. of } \\
\text { sprouts }\end{array}$ & $\begin{array}{l}\text { Sprouts/ } \\
\text { ind. }\end{array}$ & $\begin{array}{l}\text { No. of } \\
\text { sprouts }\end{array}$ & $\begin{array}{l}\text { Sprouts/ } \\
\text { ind. }\end{array}$ \\
\hline Styrax ferrugineus Nees \& Mart. & 98 & $2.3(0.7)$ & 51 & $1.2(0.8)$ & 20 & $0.5(0.9)$ \\
\hline Symplocos rhamnifolia A.DC. & 0 & $0.0(0.0)$ & 0 & $0.0(0.0)$ & 0 & $0.0(0.0)$ \\
\hline Vellozia squamata Pohl & 1 & $0.1(0.2)$ & 1 & $0.1(0.2)$ & 1 & $0.1(0.2)$ \\
\hline Total & 684 & & 375 & & 248 & \\
\hline
\end{tabular}

One growing season after each fire, most of the new basal or underground sprouts had heights up to $1.0 \mathrm{~m}$ : 96.1\% (658) after the 1998 fire, 97.0\% (363) after the 1999 fire, and $100.0 \%$ (248) after the third fire (Fig. 1a). Basal diameter smaller than or equal to $1.0 \mathrm{~cm}$ occurred in $58.8 \%$ (402) of the new sprouts after the first fire, with $48.3 \%$ (181) and 37.9\% (94) after the second and third fires. Only a small percentage had diameters greater than $2.0 \mathrm{~cm}$ (Fig. 1b). The differences in height $\left(\chi^{2}=26.4519\right.$, $P<0.05)$ and in diameter $\left(\chi^{2}=46.7141, P<0.05\right)$ between years were significant.
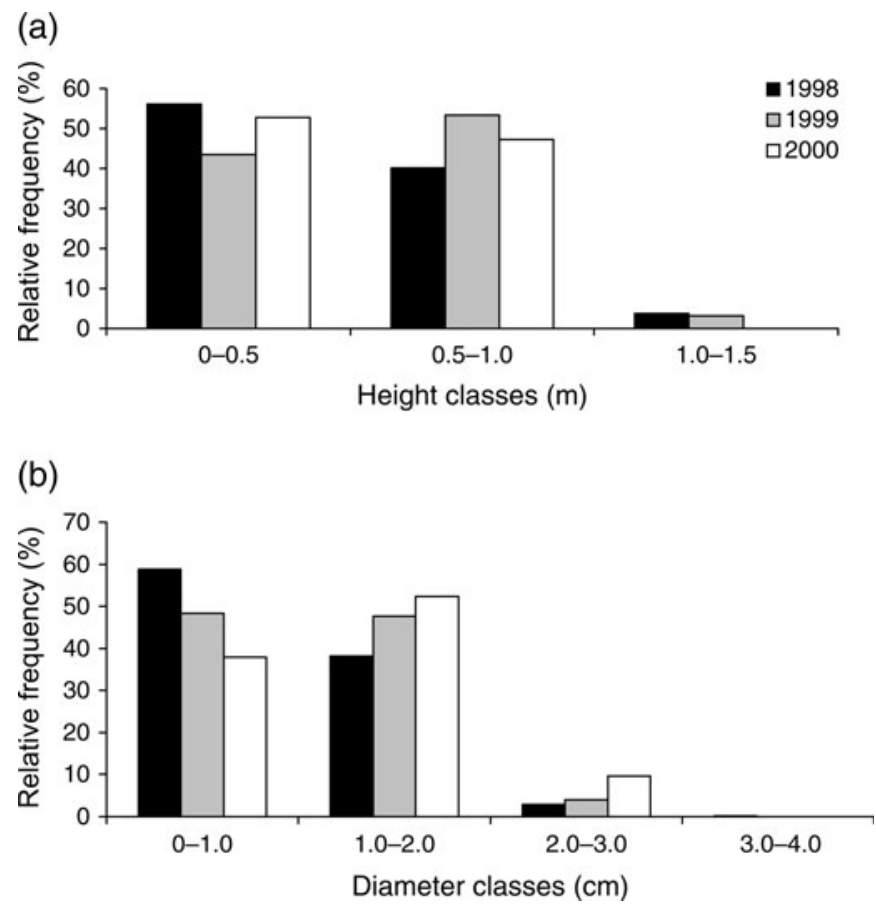

FIG. 1. Relative frequency of new basal and underground sprouts at different height (a) and diameter classes (b), after the annual controlled fires in 1998, 1999 and 2000 (total number of sprouts: $1998=684 ; 1999=375 ; 2000=248$ ). 

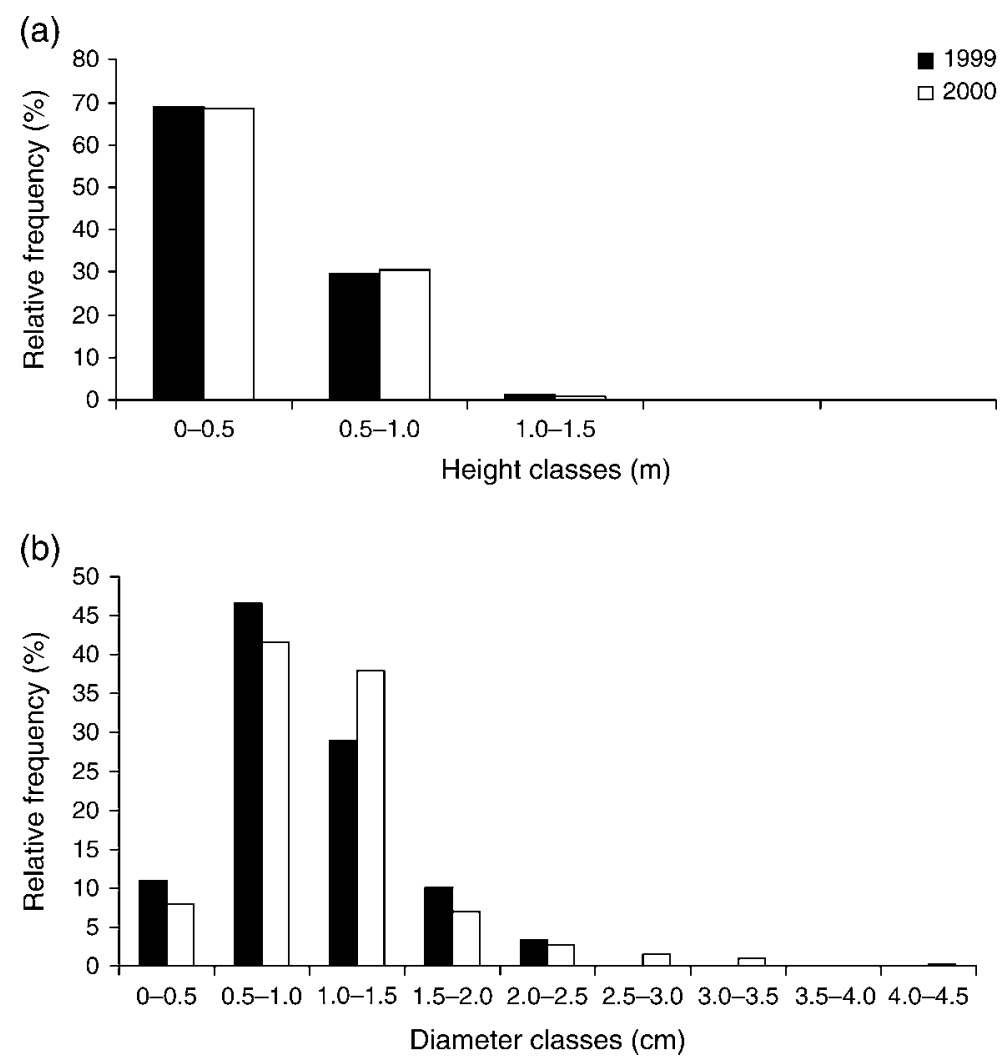

FIG. 2. Relative frequency of basal and underground sprouts that were destroyed at different height (a) and diameter classes (b), after the annual controlled fires in 1999 and 2000 (total number of dead sprouts: $1999=238 ; 2000=401$ ). Measurements were taken one year after the prescribed fires.

Mortality of basal and/or underground sprouts was high. The 1999 fire resulted in a mortality of $34.8 \%$ of the 1998 sprouts, and $37.8 \%$ of the 1999 sprouts died as a consequence of the 2000 fire.

Mortality was higher among sprouts with heights up to $0.5 \mathrm{~m}: 68.9 \%$ (164 sprouts) and 68.3\% (274) after the 1999 and 2000 fires, respectively (Fig. 2a); significant differences were not detected between the years $\left(\chi^{2}=2.7618, P>0.05\right)$. Mortality was also greater for sprouts with diameters in the range $0.5-1.0 \mathrm{~cm}: 46.6 \%(111)$ and $41.6 \%$ (99) after the 1999 and 2000 fires, respectively; and in the range 1.0-1.5 cm: $29 \%$ (69) and 37.9\% (90) after the 1999 and 2000 fires, respectively (Fig. 2b). Differences were significant $\left(\chi^{2}=14.995, P<0.05\right)$ between the years.

Figure 3 presents the height and diameter distribution of new and old sprouts after the 1999 and 2000 fires. Mortality and the destruction of vegetative organs reduced the proportion of sprouts with heights up to $0.5 \mathrm{~m}$ from $55.6 \%$ after the 1998 fire to 

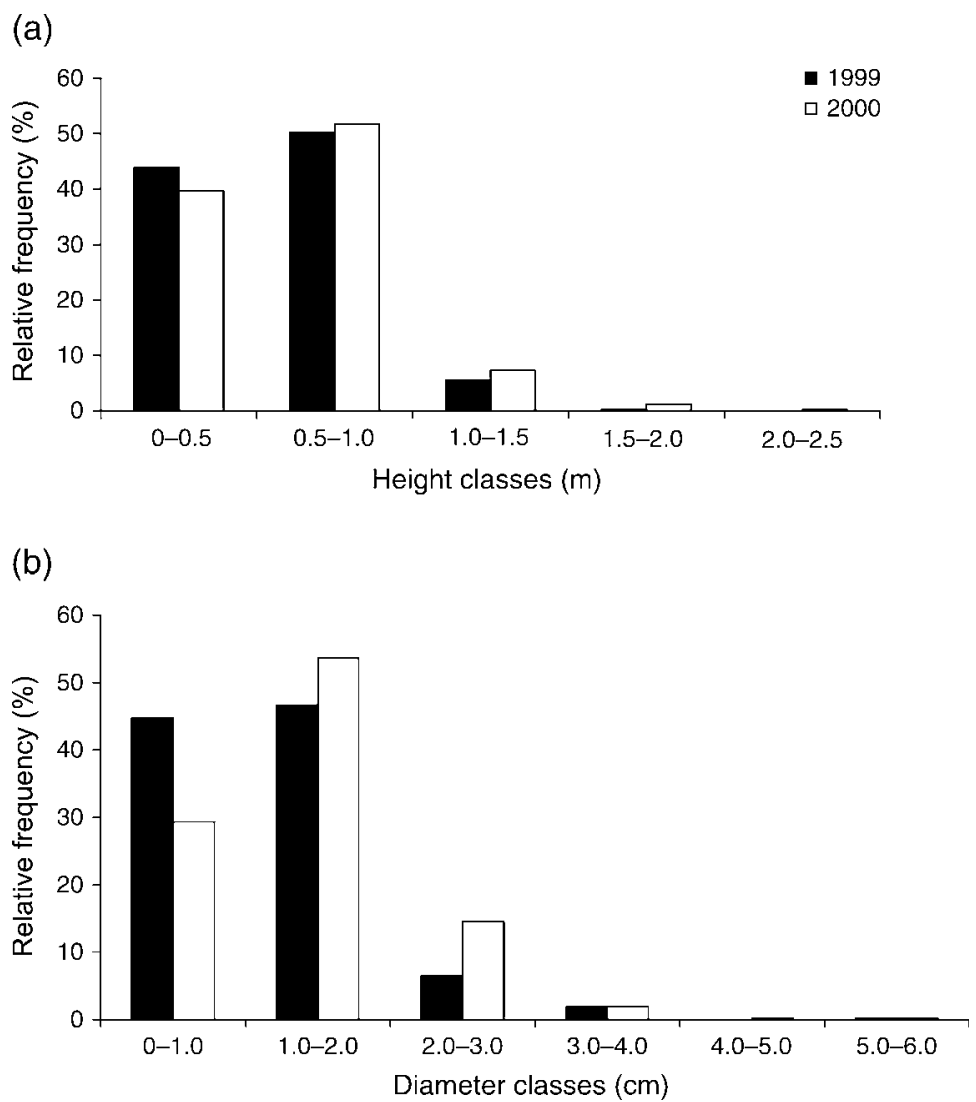

FIG. 3. Relative frequency of basal and underground sprouts accumulated at different height (a) and diameter classes (b), after the annual controlled fires in 1999 and 2000 (total number of accumulated sprouts: $1999=523 ; 2000=358$ ). Measurements were taken one year after the prescribed fires.

43.8\% and 38.0\% after the 1999 and 2000 fires, respectively. A small increase was observed in the proportion of sprouts in the height class of $0.5-1.0 \mathrm{~m}$, from $41.0 \%$ after the first fire to $48.5 \%$ and $50.7 \%$ after the second and third fires. Only a few sprouts reached a height of $2.5 \mathrm{~m}$, a result of the growth of some of the sprouts that survived the preceding fires (Fig. 3a). Differences between fires were significant $\left(\chi^{2}=44.6703, P<0.05\right)$.

A decrease in the number of sprouts with a diameter smaller than $1.0 \mathrm{~cm}$ was also observed (Fig. 3b). The 1999 and 2000 fires reduced the proportion of the sprouts with a diameter smaller than $1.0 \mathrm{~cm}$ from $47.0 \%$ after the 1999 fire to $28.4 \%$ after the 2000 fire. Some of the sprouts that resisted the three fires increased their diameter and a small proportion reached diameters up to $6.0 \mathrm{~cm}$. Differences between years were significant $\left(\chi^{2}=120.0624, P<0.05\right)$. 


\section{Species mortality}

Table 4 presents the rates of species mortality after each controlled fire. The annual fires reduced species richness from 39 to 37 species. Erythroxylum daphnites $(N=1)$ and Annona crassiflora $(N=1)$ had $100 \%$ mortality while some species with more than 10 individuals, such as Byrsonima verbascifolia, Davilla elliptica and Ouratea hexasperma, showed mortality rates lower than 10\% after the three controlled fires. In contrast Acosmium dasycarpum, Enterolobium gummiferum, Erythroxylum deciduum, Erythroxylum tortuosum, Heteropterys byrsonimifolia, Roupala montana, Rourea induta, Styrax ferrugineus and Vellozia squamata showed high mortality rates, between $23.0 \%$ and $51.8 \%$, after the first controlled fire.

\section{DISCUSSION}

The increase in the number of individuals suffering topkill (see Medeiros \& Miranda, 2005) and producing basal and/or underground sprouts after the 1999 fire, and after the succeeding one (Table 1), may be a consequence of the high fire frequencies prescribed (one-year intervals). The bark of aerial sprouts may not be thick enough to protect live tissues from the high temperatures of the flames (Rocha-Silva \& Miranda, 1996). The high proportion of individuals with aerial sprouts demonstrates an efficient protection of the cambium and dormant buds by the bark of the main stem and branches of the largest individuals (Putz \& Brokaw, 1989). The increase in the number of individuals with topkill with basal and/or underground sprouts indicates the importance of underground organs as an adaptation to fire. Souza \& Soares (1983), studying the recovery of the vegetation of a cerradão, a denser form of Cerrado, after a fire suggested that when fires are frequent the adaptations that protect the aerial parts of the woody plants are less efficient than the ones favouring sprouting from underground organs. The high proportion of individuals with sprouts in this study (Table 1) seems to confirm this statement.

For the species with only aerial sprouts (Table 2) this response may be associated with the bark characteristic of the species or in the case of Vellozia squamata by the sleeve of closely packed persistent leaf bases. For the species with three forms of resprouting, i.e. aerial, basal, underground and their combination (Table 2), the presence of different types of resprouting appears to be joint action of an effective bark protection (Rocha-Silva \& Miranda, 1996; Nefabas \& Gambiza, 2007) and the presence of underground organs (Rizzini \& Heringer, 1962).

An initial increase and a subsequent decrease in the proportion of individuals with basal and underground resprouts (Table 3) would be expected as a consequence of the increase of individuals suffering topkill (see Medeiros \& Miranda, 2005) after the successive controlled fires.

In Byrsonima coccolobifolia, Connarus suberosus, Eremanthus goyazensis, Kielmeyera coriacea, Neea theifera, Ouratea hexasperma and Styrax ferrugineus, where there is a significant reduction in the number of sprouts after the second burning (Table 3), it 
TA BLE 4. Rates of species mortality after the 1998, 1999 and 2000 controlled fires, registered in the following years $(1999,2000,2001)$ to allow time for development of sprouts

\begin{tabular}{|c|c|c|c|c|c|}
\hline \multirow[b]{2}{*}{ Species } & \multirow{2}{*}{$\begin{array}{l}\text { No. of } \\
\text { individuals } \\
\text { in } 1998\end{array}$} & \multicolumn{3}{|c|}{$\%$ mortality } & \multirow{2}{*}{$\begin{array}{l}\text { Total } \\
\text { mortality }\end{array}$} \\
\hline & & 1998 & 1999 & 2000 & \\
\hline Acosmium dasycarpum (Vogel) Yakovlev & 54 & 40.7 & 18.7 & 0.0 & 59.4 \\
\hline Andira vermifuga Mart. & 4 & 0.0 & 0.0 & 0.0 & 0.0 \\
\hline Annona crassiflora Mart. & 1 & 100.0 & 0.0 & 0.0 & 100.0 \\
\hline Aspidosperma tomentosum Mart. & 2 & 0.0 & 0.0 & 0.0 & 0.0 \\
\hline Byrsonima coccolobifolia Kunth & 7 & 0.0 & 0.0 & 0.0 & 0.0 \\
\hline Byrsonima crassa $\mathrm{Ndz}$. & 5 & 0.0 & 0.0 & 0.0 & 0.0 \\
\hline Byrsonima sp. & 1 & 0.0 & 0.0 & 0.0 & 0.0 \\
\hline Byrsonima verbascifolia (L.) DC. & 28 & 10.7 & 0.0 & 0.0 & 10.7 \\
\hline Caryocar brasiliense Cambess. & 2 & 0.0 & 50.0 & 0.0 & 50.0 \\
\hline Casearia sylvestris $\mathrm{Sw}$. & 1 & 0.0 & 0.0 & 0.0 & 0.0 \\
\hline Connarus suberosus Planch. & 14 & 21.4 & 0.0 & 0.0 & 21.4 \\
\hline Dalbergia miscolobium Benth. & 1 & 0.0 & 0.0 & 0.0 & 0.0 \\
\hline Davilla elliptica A.St.-Hil. & 92 & 7.6 & 0.0 & 0.0 & 7.6 \\
\hline Dimorphandra mollis Benth. & 12 & 0.0 & 0.0 & 0.0 & 0.0 \\
\hline Enterolobium gummiferum (Mart.) J.Macbr. & 5 & 40.0 & 0.0 & 0.0 & 40.0 \\
\hline Eremanthus goyazensis (Gardn.) Sch.Bip. & 37 & 13.5 & 3.1 & 0.3 & 16.9 \\
\hline Erythroxylum daphnites Mart. & 1 & 100.0 & 0.0 & 0.0 & 100.0 \\
\hline Erythroxylum deciduum A.St.-Hil. & 8 & 25.0 & 0.0 & 0.0 & 25.0 \\
\hline Erythroxylum suberosum A.St.-Hil. & 22 & 10.0 & 0.0 & 5.0 & 15.0 \\
\hline Erythroxylum tortuosum Mart. & 2 & 50.0 & 0.0 & 0.0 & 50.0 \\
\hline Hancornia speciosa Gomez & 1 & 0.0 & 0.0 & 0.0 & 0.0 \\
\hline Heteropterys byrsonimifolia A.Juss. & 2 & 50.0 & 0.0 & 0.0 & 50.0 \\
\hline Kielmeyera coriacea (Spreng.) Mart. & 37 & 18.9 & 0.0 & 3.3 & 22.2 \\
\hline Miconia albicans (Sw.) Triana & 1 & 0.0 & 0.0 & 0.0 & 0.0 \\
\hline Neea theifera Oerst. & 6 & 0.0 & 16.6 & 0.0 & 16.6 \\
\hline Ouratea hexasperma (A.St.-Hil.) Baill. & 38 & 7.9 & 0.0 & 2.7 & 10.6 \\
\hline Palicourea rigida Kunth & 7 & 0.0 & 14.3 & 0.0 & 14.3 \\
\hline Piptadenia sp. & 1 & 0.0 & 0.0 & 0.0 & 0.0 \\
\hline Psidium pohlianum O.Berg & 1 & 0.0 & 0.0 & 0.0 & 0.0 \\
\hline Qualea grandiflora Mart. & 9 & 0.0 & 0.0 & 0.0 & 0.0 \\
\hline Qualea parviflora Mart. & 3 & 0.0 & 0.0 & 0.0 & 0.0 \\
\hline Roupala montana Aubl. & 123 & 43.1 & 7.1 & 7.7 & 57.9 \\
\hline Rourea induta Planch. & 20 & 40.0 & 0.0 & 6.2 & 46.2 \\
\hline Schefflera macrocarpa (Seem.) D.C.Frodin & 4 & 0.0 & 0.0 & 0.0 & 0.0 \\
\hline Stryphnodendron adstringens (Mart.) Cov. & 4 & 0.0 & 0.0 & 0.0 & 0.0 \\
\hline Styrax ferrugineus Nees \& Mart. & 42 & 23.8 & 0.0 & 5.7 & 29.5 \\
\hline Symplocos rhamnifolia A.DC. & 4 & 0.0 & 0.0 & 0.0 & 0.0 \\
\hline Vellozia squamata Pohl & 34 & 35.3 & 0.0 & 16.0 & 51.3 \\
\hline
\end{tabular}


seems that annual fires will affect the structure of the different species populations. Disturbance frequency models have been invoked to explain patterns of resprouting (Morrison et al., 1995; Clarke \& Knox, 2002).

The small heights and basal diameters reached after the controlled fires (Fig. 1) could explain the decrease in the number of sprouts after the first burning. Species with fast development of sprouts may be more competitive than species with regeneration from seeds, since seedlings and juveniles will need to allocate a large amount of reserves to underground organs that will allow resprouting after drought or fire (Oliveira \& Silva, 1993; Moreira \& Klink, 2000) and having lower heights will be more susceptible to fire damage. However, the mechanisms responsible for declines in sprouting ability may include a number of causes (Vesk, 2006), such as bud senescence (Vesk \& Westoby, 2004) and the number of surviving meristems (Bond \& Midgley, 2001).

The reduction in the number of sprouts (old + new) after the successive fires indicates that the vegetation is not adapted to such a high fire frequency. One year may not be long enough for the sprouts to produce a thick enough bark to protect live tissue during fires (Gignoux et al., 1997; Hoffmann \& Solbrig, 2003) or to grow tall enough to escape the zone of high temperatures (Miranda et al., 1993).

The higher mortality of sprouts with height up to $0.5 \mathrm{~m}$ (Fig. 2a) may be because the highest air temperature during Cerrado fires occurs mostly at $60 \mathrm{~cm}$ (Miranda et al., 1993), so that most sprouts with a height up to $0.5 \mathrm{~m}$ (Fig. 1a) would suffer mortality unless effective bark insulation was achieved. The small diameter of the sprouts between $0.5-1.5 \mathrm{~cm}$ (Fig. 2b) may have been the main determinant of the high mortality rates for sprouts. Critical values of height and diameter for mortality by fire have been established for Cerrado vegetation and vary considerably among stages of development. Medeiros \& Miranda (2005) have shown that for campo sujo fires more than $90 \%$ of the mortality of the woody vegetation after annual fires occurs in individuals which are less than $5 \mathrm{~cm}$ in diameter, independent of height. Hoffmann \& Solbrig (2003) observed increased stem mortality for individuals with a diameter smaller than $0.4 \mathrm{~cm}$. Both studies showed that a high proportion of individuals in small diameter classes will recover to pre-fire size after one year. In fact, there is no clear relationship between height and sprouting ability (Meyer et al., 2005), and diameter seems a better indicator for individual survival. However, for large individuals the damage means a considerable loss of biomass which is not quickly recovered, suggesting that greater time intervals should be allowed between fires.

The species mortality rates were higher after the first controlled fire as a consequence of the high mortality (93\%) of individuals with a diameter smaller than $5 \mathrm{~cm}$ (see Medeiros \& Miranda, 2005), suggesting that the mortality rate was related to direct effects of fire and bark thickness. The sprouting indices (Eq. 1) were 1.4, 1.3 and 1.0 after the first, second and third prescribed fires, respectively, indicating the effect of recurrent fires in reducing the number of sprouts.

It seems that there is no relation between sprouting capacity and species survival. The species that showed mortality rates lower than $10 \%$, such as Byrsonima 
verbascifolia, Davilla elliptica and Ouratea hexasperma (Table 4), also have a variety of sprouting capacity (Table 3). So, for these species, the resistance against fires offered by bark insulation may be more effective than the sprouting capacity.

Some species, such as Roupala montana, Rourea induta and Styrax ferrugineus, that show high mortality rates (Table 4) also have high sprouting capacity (Table 3 ). These species also suffer high mortality under wildfire events in denser forms of Cerrado (Felfili et al., 2000), suggesting a trend for reduction of species richness with successive fires, as Nefabas \& Gambiza (2007) observed in an African savanna.

The high mortality rates of woody individuals and species, the large number of individuals with topkill, the reduction in the number of new sprouts, and the low survival rate of the sprouts indicate that a one-year interval between fires is insufficient for vegetative recovery of the woody Cerrado vegetation and results in changes in the structure and composition of the vegetation by reducing height and density of woody individuals.

\section{ACKNOWLEDGEMENTS}

The authors acknowledge the useful suggestions of Dr Manoel Cláudio Silva Jr., Dr John Hay, Dr Helena Morais, Dr José Felipe Ribeiro, Dr Linda S. Caldas and the anonymous reviewers, and the help with data collection and field work given by Pedro Olavo, Antônio Gumiero and Diassis Alvarenga. We are especially grateful to Maria Iracema Gonzáles from the Brazilian Institute of Geography and Statistics (IBGE) and to the Fire Crew Members of IBGE. The United States Department of Agriculture/Forest Service (USDA/FS) and the Brazilian National Council for Scientific and Technological Development/Long Term Ecological Research Program (CNPq/PELD) provided financial support.

\section{REFERENCES}

Agee, J. K. (1993). Fire Ecology of Pacific Northwest Forests. New York: Island Press. Ayres, M., Ayres, M., Jr., Ayres, D. L. \& Santos, A. S. (2003). Bioestat 3.0. Aplicaçôes estatísticas nas áreas das ciências biológicas e médicas. Manaus: Sociedade Civil Mamirauá/MCT-CNPq/Conservation International.

Bond, W. J. \& Midgley, J. J. (2001). Ecology of sprouting in woody plants: the persistence niche. Trends Ecol. Evol. 16: 45-51.

Bond, W. J. \& Wilgen, B. W. (1996). Fire and Plants. New York: Chapman \& Hall.

Braz, V. S., Kanegae, M. F. \& Franco, A. C. (2000). Estabelecimento e desenvolvimento de Dalbergia miscolobium Benth. em duas fitofisionomias típicas dos cerrados do Brasil Central. Acta Bot. Brasil. 14: 27-35.

Clarke, P. J. \& Knox, K. J. E. (2002). Post-fire response of shrubs in the tablelands of eastern Australia: do existing models explain habitat differences? Austral. J. Bot. 50: 53-62.

Coutinho, L. M. (1990). Fire in the ecology of the Brazilian cerrado. In: Goldammer, J. G. (ed.) Fire in the Tropical Biota, pp. 82-105. Berlin: Springer-Verlag.

Dias, B. F. S. (1992). Cerrados: uma caracterização. In: Dias, B. F. S.(org.) Cerrados, pp. 11-25. Brasília: FUNATURA.

Eiten, G. (1972). The Cerrado vegetation of Brazil. Bot. Rev. 38: 201-341. 
Felfili, J. M., Rezende, A. V., Silva Júnior, M. C. \& Silva, M. A. (2000). Changes in the floristic composition of cerrado sensu stricto in Brazil over a nine-year period. J. Trop. Ecol. 16: 579-590.

Frost, P. G. H. \& Robertson, F. (1987). The ecological effects of fire in savannas. In: W ALker, B. H. (ed.) Determinants of Tropical Savannas, pp. 93-140. Oxford: IRL Press.

Gignoux, J., Clobert, J. \& Menaut, J-C. (1997). Alternative fire resistance strategies in savanna trees. Oecologia 110: 576-583.

Hoffmann, W. A. (1998). Post-burn reproduction of woody plants in a neotropical savanna: the relative importance of sexual and vegetative reproduction. J. Appl. Ecol. 35: 422-433.

Hoffmann, W. A. (1999). Fire and population dynamics of woody plants in a neotropical savanna: matrix model projections. Ecology 80: 1354-1369.

Hoffmann, W. A. \& Solbrig, O. T. (2003). The role of topkill in the differential response of savanna woody species to fire. Forest Ecol. Manag. 180: 273-286.

Kauffman, J. B. (1991). Survival by sprouting following fire in tropical forests of the Eastern Amazon. Biotropica 23: 219-224.

Medeiros, M. B. \& Miranda, H. S. (2005). Mortalidade pós-fogo em espécies lenhosas de campo sujo submetido a três queimadas prescritas anuais. Acta Bot. Brasil. 19: 493-500.

Meyer, K. M., Ward, D., Moustakas, A. \& Wiegand, K. (2005). Big is not better: small Acacia mellifera shrubs are more vital after fire. Afr. J. Ecol. 43: 131-136.

Miranda, A. C., Miranda, H. S., Dias, I. F. O. \& Dias, B. F. S. (1993). Soil and air temperatures during prescribed Cerrado fires in Central Brazil. J. Trop. Ecol. 9: 313-320.

Miranda, H. S. \& Sato, M. N. (2005). Efeitos do fogo na vegetação lenhosa do Cerrado. In: Scariot, A., Sousa-Silva, J. C. \& Felfili, J. M. (eds) Cerrado: ecologia, biodiversidade e conservação, pp. 93-106. Brasília: Ministério do Meio Ambiente.

Moreira, A. G. \& KLink, C. A. (2000). Biomass allocation and growth of tree seedlings from two contrasting Brazilian savannas. Ecotropicos 13: 43-51.

Morrison, D. A., Cary, G. J., Pengelly, S. M., Ross, D. G., Mullins, B. J., Thomas, C. R. \& Anderson, T. S. (1995). Effects of fire frequency on plant species composition of sandstone communities in the Sydney region: inter-fire interval and timesince-fire. Austral. J. Ecol. 20: 239-247.

Nefabas, L. L. \& Gambiza, J. (2007). Fire-tolerance mechanisms of common woody plant species in a semiarid savanna in south-western Zimbabwe. Afr. J. Ecol. 45: 550-556.

Oliveira, P. E. A. M. \& Gibis, P. E. (2000). Reproductive biology of woody plants in a cerrado community of Central Brazil. Flora 195: 311-329.

Oliveira, P. E. A. M. \& Silva, J. C. (1993). Reproductive biology of two species of Kielmeyera (Guttiferae) in the cerrados of central Brazil. J. Trop. Ecol. 9: 67-79.

Putz, N. E. \& Brokaw, N. V. L. (1989). Sprouting of broken trees on Barro Colorado Island, Panama. Ecology 70: 508-512.

Ramos, A. E. (1990). Efeitos da queima sobre a vegetação lenhosa do cerrado. MSc thesis, Universidade de Brasília, Brasília, DF.

Ribeiro, J. F. \& Walter, B. M. T. (1998). Fisionomias do bioma Cerrado. In: Sano, S. M. \& Almeida, S. P. (eds) Cerrado, Ambiente e Flora, pp. 89-166. Planaltina: EMBRAPA.

Rizzini, C. T. \& Heringer, E. P. (1962). Studies on the underground organs of trees and shrubs from some southern Brazilian savannas. Anais Acad. Brasil. Ci. 34: 235-248.

Rocha-Silva, E. P. \& Miranda, H. S. (1996). Temperatura do câmbio de espécies lenhosas do cerrado durante queimadas prescritas. In: Pereira, R. C. \& NAsser, L. C. B. (eds) Anais do VII Simpósio sobre o Cerrado, pp. 253-257. Planaltina: EMBRAPA-CPAC, Brazil. 
Souza, M. H. A. O. \& Soares, J. J. (1983). Brotamento de espécies arbustivas e arbóreas posteriormente a uma queimada num cerradão. Anais do Seminário Regional de Ecologia 3: $263-275$.

Vesk, P. A. (2006). Plant size and resprouting ability: trading tolerance and avoidance of damage? J. Ecol. 94: 1027-1034.

Vesk, P. A. \& Westoby, M. (2004). Funding the bud bank: a review of the costs of buds. Oikos 106: 200-208.

Received 15 March 2007; accepted for publication 21 November 2007 